\title{
Assessing the synergistic relationship of mycorrhiza and bacteria for the degradation of spent engine oil in maize grown soil
}

Ayokunle Samuel Bolaji ${ }^{1,2^{*}}$, Mojeed Olaide Liasu' ${ }^{1}$, Abiodun Ayanfemi Ayandele ${ }^{1}$ and John Ayobami Amao ${ }^{3}$

\begin{abstract}
Background: Pollution by waste hydrocarbons on soil and water bodies is an endemic problem in African countries, particularly in Nigeria. This has caused untold hardship and increase in poverty level of the people, due to the pollution of water and land; which had direct impacts on the livelihood of people. Several species of bacteria that can degrade hydrocarbon had been isolated from the root of plants. The aim of this work was to determine the ability of rhizosphere bacteria to degrade spent engine oil (SPO) in the presence of arbuscular mycorrhiza fungus.

Results: The total aerobic count in the eight treatments ranged between $3.0 \times 10^{6}$ and $1.18 \times 10^{8} \mathrm{CFU} / \mathrm{g}$. No significant difference was observed in the total aerobic count among the treatments except when compared with the control experiment $(\mathrm{M}-\mathrm{C}-$ ). Isolated bacteria from the polluted soil samples were identified by 165 rRNA sequencing as Bacillus cereus, Pseudomonas aeruginosa, Bacillus amyloliquefaciens, Lysinibacillus fusiformis, Bacillus enecimensis, and Paraclostridium benzoelyticum. Four of the bacteria were able to utilize spent engine oil effectively to different degrees. However, Lysinibacillus fusiformis biodegraded spent engine oil by 40\%, Paraclostridium benzoelyticum by $30 \%$ and Bacillus enecimensis by $20 \%$ after 28 days of incubation. The infrared analysis result revealed that Lysinibacillus fusiformis (P6) reduced the strong and band of alcohol by $44 \%$, carboxylic acid group by $22 \%$ and carbonyl group by $27 \%$, respectively. This study revealed that spent engine oil at a minimum value of $50 \mathrm{mg} / \mathrm{kg}$ with arbuscular mycorrhiza fungus in the soil samples resulted in better growth for maize plant and higher total aerobic count.
\end{abstract}

Conclusions: It can thus be concluded that arbuscular mycorrhiza fungus positively impacts the ability of rhizosphere bacteria in the degradation of spent engine oil and the growth of maize plant on contaminated soil.

Keywords: Biodegradation, Residual oil, Mycorrhiza, spent engine oil, contamination

\section{Introduction}

The discharge of spent oil into the environment brings about pollution, which is an undesirable change in the physical, chemical and biological characteristics of all the components of an environment (Aboribo, 2001).

\footnotetext{
*Correspondence: ayokunlebolaji@gmail.com

'Department of Pure and Applied Biology, Faculty of Science, Ladoke

Akintola University of Technology, P.M.B, Ogbomoso 4000, Nigeria

${ }^{2}$ Department of Science Laboratory Technology, Federal Polytechnic, Ede

Osun State, Nigeria

Full list of author information is available at the end of the article
}

The increasing uses of automobiles and other heavy equipment have resulted in the increased consumption of hydrocarbon products; and invariably, the contamination of soil and water bodies. This often results in the distortion of soil physical, biological, and chemical properties (Stephen et al. 2013).

Soil contamination by hydrocarbons causes extensive damage to the ecosystems and leads to the accumulation of pollutants in animals and plants tissue, which may cause progeny's death or mutation (Alvarez et al. 1991). Spent engine oil on land may cause damage to the 
environment in many ways like the retardation of vegetation growth and cause of soil fertility loss for a long period of time until natural processes re-establish stability (Sada and Odemerho, 2000). Contaminated soil possess high concentrations of chemicals and other substances derived from various man's use of land, thereby influencing surface and ground water quality, the nature and viability of ecosystems and invariably plant, animal, and human health (Vegter et al. 2002).

Many bacteria are known to stimulate plant growth through direct or indirect interactions with plant roots (Hashem et al. 2019). Bioremediation involves indigenous oil-consuming microorganism by enhancing and fertilizing them in their natural habitats (Heider and Rabus, 2008). Microorganisms degrade pollutant compounds by using enzymes in their metabolism and can be useful in cleaning up contaminated sites (Alexander et al. 1997). Vazquez et al. (2000) reported that several rhizospheres colonizing bacteria such as Azotobacter, Azospirillum, Bacillus, Clostridium, and Pseudomonas were found to produce substances that stimulate plant growth or inhibit root pathogens. The establishment of Mycorrhiza implies profound morphological and physiological changes in the root which operates in an inclusive manner with the fungus, promoting increase adaptation, and survival of symbionts (Teste et al. 2009). A fungus of great importance for agriculture in this type of association is Arbuscular Mycorrhiza fungus (AMF). This study therefore aimed at determining the ability of rhizosphere bacteria to degrade spent engine oil in the presence of arbuscular mycorrhiza fungus.

\section{Materials and methods}

\section{Sample collection}

Uncultivated soil samples were collected from a part of Abogunde Sagba area (Latitude $7^{\circ} 7^{\prime} 38.58^{\prime \prime} \mathrm{N}$ Longitude $4^{\circ} 42^{\prime} 10.21^{\prime \prime} E$ ) in Ede, Osun State, Nigeria. This was done at a depth of $10 \mathrm{~cm}$ deep using the "V-shaped" soil sampling method, with the aid of a spade in a zig-zag manner to ensure homogeneity.

\section{Experimental design}

After a thorough mixing of the soil samples, $3 \mathrm{~kg}$ each was transferred into different nursery planting bags. Two experimental soil groups were set up (one with mycorrhiza and the other without mycorrhiza) for three treatments of different spent engine oil concentrations added (50, 75, and $100 \mathrm{mg} / \mathrm{kg}$ ). Two controls (one with mycorrhiza only and one without any treatment) were also set-up. The experimental soil samples were then planted with maize seeds (Zea mays). Soil samples were taken from the maize plant root area at a space of 0,7 , $14,21,28,35$, and 42 days. Total aerobic counts of the samples were carried out. The experimental set-up consisted of contamination with spent engine oil as the first factor designated $\mathrm{C}$ at two levels (contaminated $\mathrm{C}+$ and uncontaminated $\mathrm{C}-$ ). The second factor was the inoculation with mycorrhiza (Glomus muse) designated $\mathrm{M}$ also at two levels (inoculated $\mathrm{M}+$ and not inoculated $\mathrm{M}-$ ). The two factors were arranged in factorial combination to give four treatments each, namely, (in milligram per kilogram): $\mathrm{M}+\mathrm{C}-, \mathrm{M}+\mathrm{C}+50, \mathrm{M}+\mathrm{C}+75, \mathrm{M}+\mathrm{C}+100, \mathrm{M}-\mathrm{C}$ $-, \mathrm{M}-\mathrm{C}+50, \mathrm{M}-\mathrm{C}+75$, and $\mathrm{M}-\mathrm{C}+100$.

\section{Total aerobic count}

Soil samples were serially diluted and plated out on Nutrient agar using the pour plate method (Nwite and Alu, 2015). Plates were inoculated with $1 \mathrm{ml}$ of diluents and incubated at $35 \pm 2{ }^{\circ} \mathrm{C}$ for $24 \mathrm{~h}$. Grown plates were counted under the colony counter.

\section{Bacteria isolation and characterization}

Bacteria with persistent occurrence (based on morphological characteristics) were picked and streaked until pure colonies were obtained.

\section{Oil degrading test}

Bacterial isolates obtained were grown in minimal salt medium (broth and agar) containing $10.0 \mathrm{~g} \mathrm{NaCl} ; 0.42 \mathrm{~g}$ $\mathrm{MgSO}_{4} ; 0.83$ g KH$_{2} \mathrm{PO}_{4} ; 1.25$ g NaPO$_{4} ; 0.42 \mathrm{~g} \mathrm{NaNO}_{3}$; $0.29 \mathrm{~g} \mathrm{KCl}$; and $15 \mathrm{~g} \mathrm{Agar,} \mathrm{while} \mathrm{spent} \mathrm{engine} \mathrm{oil} \mathrm{was}$ added as the sole carbon source in the broth (Banks et al. 2003), filter paper soaked in spent engine oil were used on agar plates (Ajoy et al. 2012); these were incubated at 37 ${ }^{\circ} \mathrm{C}$ for 7 days.

\section{Bacterial characterization}

Pure cultures of the bacterial isolates were subjected to morphological and biochemical characterization like citrate test, sugar utilization, motility test, and catalase test among others (Ajoy et al. 2012). The 16S rRNA of the bacterial isolates were amplified and sequenced (Amao et al. 2019) using universal primer 518F (CCAGCAGCCG CGGTAATACG) and 800R (TACCAGGGTATCTAAT $\mathrm{CC})$. The sequence was performed using a Sanger sequencer. The bacterial sequences were submitted to the NCBI.

\section{Hydrocarbon degradation assay}

The hydrocarbon degradation assay was carried out using the mineral salt medium (MSM) as adopted by Sepahi et al. (2008). After sterilization and cooling, $5 \mathrm{ml}$ of sterile engine oil and $2 \mathrm{ml}$ inoculums of the hydrocarbon utilizing bacteria were added to each bottle. Un-inoculated bottle of sterile MSM and spent engine oil were set up as control. The bottles were incubated at $37{ }^{\circ} \mathrm{C}$ for 21 days as described by Ukaegbu and Mbakwem (2014). 
Table 1 Effect of spent engine oil and mycorrhiza on the number of leaves per plotted maize plant

\begin{tabular}{lllllll}
\hline Treatment & \multicolumn{5}{c}{ Number of leaves in maize plant in days } \\
\cline { 2 - 7 } & 7 & 14 & 21 & 28 & 35 & 42 \\
\hline$M-C-$ & $3.00 \pm 0.01$ & $5.00 \pm 0.01$ & $6.00 \pm 0.01$ & $6.33 \pm 0.47$ & $7.00 \pm 0.47$ & $8.33 \pm 0.47$ \\
$M+C$ & $3.00 \pm 0.01$ & $5.00 \pm 0.82$ & $6.00 \pm 0.47$ & $7.60 \pm 0.47$ & $10.00 \pm 0.47$ & $11.00 \pm 0.82$ \\
$M+C+50$ & $3.00 \pm 0.01$ & $5.00 \pm 0.47$ & $6.00 \pm 0.47$ & $6.00 \pm 0.47$ & $9.00 \pm 0.47$ & $13.00 \pm 0.47$ \\
$M+C+75$ & $3.00 \pm 0.47$ & $5.00 \pm 0.47$ & $6.00 \pm 0.94$ & $6.00 \pm 0.47$ & $6.30 \pm 0.47$ & $12.00 \pm 0.47$ \\
$M+C+100$ & $3.00 \pm 0.58$ & $5.00 \pm 0.58$ & $6.00 \pm 0.58$ & $6.00 \pm 0.58$ & $6.30 \pm 1.53$ & $8.33 \pm 1.16$ \\
$M-C+50$ & $3.00 \pm 0.47$ & $4.30 \pm 0.47$ & $6.00 \pm 0.47$ & $6.30 \pm 0.47$ & $8.00 \pm 0.47$ & $9.30 \pm 0.47$ \\
$M-C+75$ & $3.30 \pm 0.47$ & $4.30 \pm 0.47$ & $5.60 \pm 0.47$ & $6.60 \pm 0.47$ & $7.00 \pm 0.47$ & $8.30 \pm 0.47$ \\
$M-C+100$ & $2.60 \pm 0.47$ & $3.60 \pm 0.47$ & $5.00 \pm 0.47$ & $5.60 \pm 0.47$ & $7.30 \pm 0.47$ & $7.60 \pm 0.47$ \\
\hline
\end{tabular}

\section{Extraction of residual oil}

The residual spent engine oil in the experimental and the control set up after the incubation period were extracted by the liquid-liquid solvent extraction method using chloroform. Twenty milliliter of chloroform was measured into each of the bottles and the content of each bottle was transferred into a separating funnel (Ayandele et al. 2012). The funnel was allowed to stand for $30 \mathrm{~min}$, the layer of the organic solvent and oil was emptied into sterile Petri dishes, and the MSM-organism layer was discarded. The organic solvent was allowed to evaporate from the residual oil and the residual oil was measured using a pipette.

\section{Infrared analysis}

The residual oil from both experimental and control bottles after the 28 days incubation period was subjected to infrared (IR) analysis at the Multi-disciplinary Central Research Laboratory of the University of Ibadan, Oyo State, Nigeria.

\section{Results}

The number of leaves in treatment $\mathrm{M}+\mathrm{C}$ - increased to 11 leaves while that in $\mathrm{M}+\mathrm{C}+50$ increased to 13 at the expiration of the experiment. The ANOVA showed a significant difference at $P<0.05$, observed in the number of leaves in both treatments $(\mathrm{M}+\mathrm{C}-$ and $\mathrm{M}+\mathrm{C}+75)$ compared with the control (Table 1). There was a steady increase in the shoot height of the control treatment and the others throughout the planting period. The $\mathrm{M}+\mathrm{C}-$ showed a rapid shoot growth till the expiration of the experiment with mean value of $65 \mathrm{~cm}$ in height. Both the control (M-C-) and $\mathrm{M}+\mathrm{C}+50$ had increased shoot height with different height at the end of the experiment (Table 2). Bacteria count in the control treatment $(\mathrm{M}-\mathrm{C}-)$ ranged from $3.0 \times 10^{6}$ to $3.12 \times 10^{7} \mathrm{CFU} / \mathrm{g}$. The bacteria count in the rhizosphere soil treatment inoculated with $\mathrm{AM}$ fungi $\mathrm{M}+\mathrm{C}$ - ranged from $2.23 \times 10^{7}$ to $1.02 \times 10^{8} \mathrm{CFU} / \mathrm{g}$ count but later declined at 6 weeks planting period. The bacteria count in inoculated rhizosphere soil treatment with AM fungi and contamination with $50 \mathrm{mg} / \mathrm{kg}$ of spent oil ranged from $2.13 \times 10^{7}$ to $9.13 \times 10^{7} \mathrm{CFU} / g$, respectively (Fig. 1 ).

The bacteria count in soil with AM fungi and contaminated with $75 \mathrm{mg} / \mathrm{kg}$ of spent engine oil ranged from $2.13 \times 10^{7} \mathrm{CFU} / \mathrm{g}$ to $9.9 \times 10^{7} \mathrm{CFU} / \mathrm{g}$. The bacteria count in $\mathrm{M}+\mathrm{C}+75$ began with $2.13 \times 10^{7} \mathrm{CFU} / \mathrm{g}$ and increased gradually throughout the weeks of planting (Fig. 2). Three of the 8 bacterial isolates were

Table 2 Effect of spent engine oil and mycorrhiza fungi on the shoot height per plotted maize plant

\begin{tabular}{|c|c|c|c|c|c|c|}
\hline \multirow[t]{2}{*}{ Treatment } & \multicolumn{6}{|c|}{ Shoot height in maize plant in days } \\
\hline & 7 & 14 & 21 & 28 & 35 & 42 \\
\hline $\mathrm{M}-\mathrm{C}-$ & $7.66 \pm 0.47$ & $36.67 \pm 1.25$ & $36.67 \pm 1.25$ & $45.00 \pm 0.82$ & $50.33 \pm 0.47$ & $61.00 \pm 0.25$ \\
\hline $\mathrm{M}+\mathrm{C}-$ & $17.67 \pm 0.47$ & $34.67 \pm 0.33$ & $41.33 \pm 1.89$ & $49.33 \pm 2.49$ & $55.67 \pm 2.06$ & $65.00 \pm 5.10$ \\
\hline$M+C+50$ & $14.00 \pm 1.49$ & $33.33 \pm 4.11$ & $36.33 \pm 2.63$ & $44.67 \pm 3.77$ & $52.67 \pm 5.44$ & $55.67 \pm 5.19$ \\
\hline$M+C+75$ & $14.00 \pm 0.82$ & $35.00 \pm 0.82$ & $41.33 \pm 1.88$ & $46.33 \pm 3.09$ & $50.00 \pm 0.82$ & $55.00 \pm 1.41$ \\
\hline$M+C+100$ & $14.33 \pm 0.57$ & $23.33 \pm 4.00$ & $28.67 \pm 4.00$ & $30.67 \pm 4.00$ & $35.33 \pm 1.57$ & $40.00 \pm 2.65$ \\
\hline$M-C+50$ & $7.67 \pm 0.47$ & $36.00 \pm 0.82$ & $38.00 \pm 0.81$ & $47.33 \pm 0.47$ & $58.67 \pm 0.47$ & $73.33 \pm 0.94$ \\
\hline$M-C+75$ & $6.37 \pm 0.01$ & $32.33 \pm 0.47$ & $38.33 \pm 0.47$ & $46.67 \pm 1.25$ & $52.33 \pm 0.94$ & $59.67 \pm 0.47$ \\
\hline$M-C+100$ & $6.80 \pm 2.70$ & $35.67 \pm 0.47$ & $35.93 \pm 0.47$ & $36.33 \pm 0.47$ & $48.00 \pm 0.12$ & $50.00 \pm 1.82$ \\
\hline
\end{tabular}




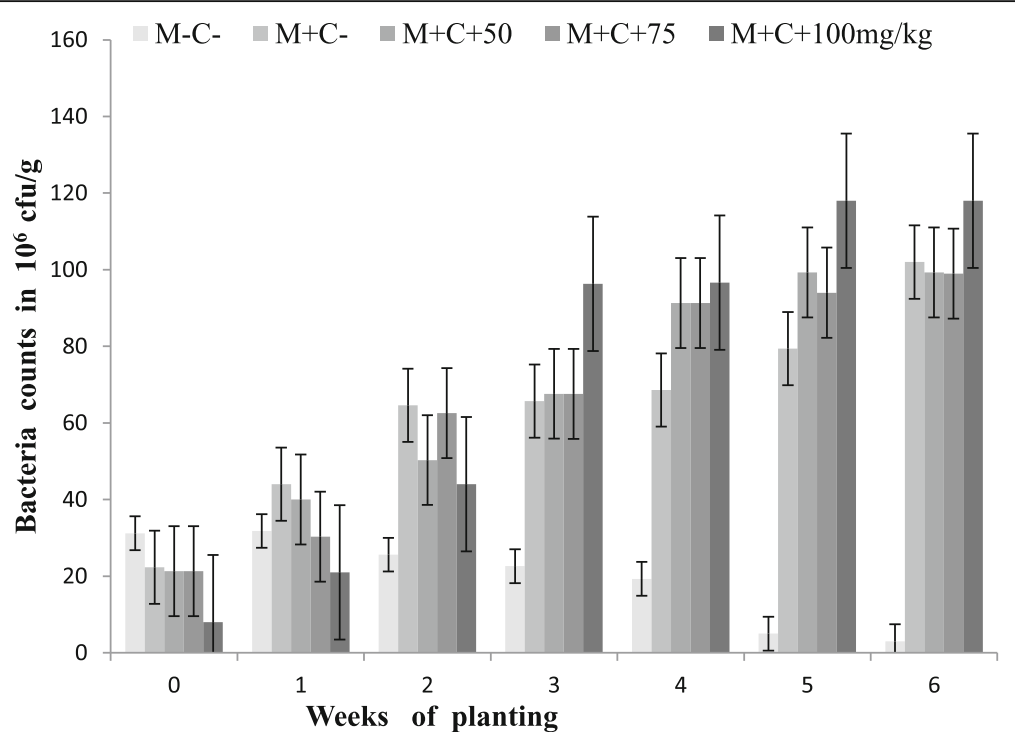

Fig. 1 Effect of inoculation with AM fungi and contamination with spent engine oil on the mean counts of bacteria in CFU/g dilution

Gram-negative. Seven were positive for motility test, and 6 were positive for catalase test (Table 3). Four were identified as members of the genus Bacillus, two were Pseudomonas, one was Lysinibacillus, and the remaining one was Paraclostridium (Table 4). Bacillus cereus, Lysinibacillus fusiformis, Bacillus encimensis, and Paraclostridium benzoelyticum utilized the spent oil effectively (Table 5). Lysinibacillus fusiformis utilized $40 \%$ of utilized engine oil, Paraclostridium benzoelyticum utilized engine oil up to $30 \%$; while Bacillus encimensis utilized up to $20 \%$ of spent engine oil and Bacillus cereus was able to utilize $12 \%$ of spent engine oil (Table 6).

The control contained carbonyl group $\mathrm{C}=\mathrm{O}\left(1700 \mathrm{~cm}^{-1}\right)$ with $74 \%$ absorbance $(26 \% \mathrm{~T})$ or $\mathrm{C}=\mathrm{C}$ stretch of ketone and alkenes $\mathrm{SP}^{2} \mathrm{C}-\mathrm{H}$ stretch of substituted benzene (728 $\mathrm{cm}^{-1}$ ) with $80 \%$ absorbance $(20 \% \mathrm{~T})$ respectively. The IR bands of $3405 \mathrm{~cm}^{-1}$ with $20 \% \mathrm{~T}, 2733 \mathrm{~cm}^{-1}$ with $21 \% \mathrm{~T}$, $1667 \mathrm{~cm}^{1}$ with $22 \% \mathrm{~T}$ and $728 \mathrm{~cm}^{-1}$ with $18 \% \mathrm{~T}$ respectively were observed for Bacillus cereus. It also revealed that the injected sample with Bacillus cereus contained all

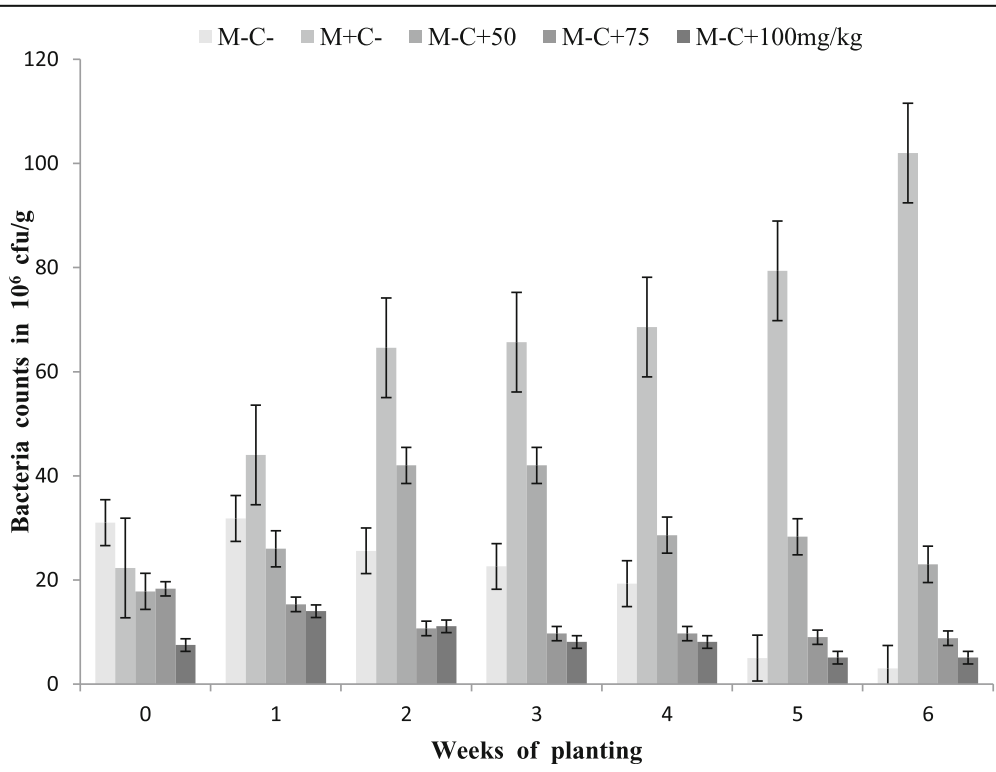

Fig. 2 Effect of contamination with spent engine oil on the mean counts of bacteria in CFU/g dilution 


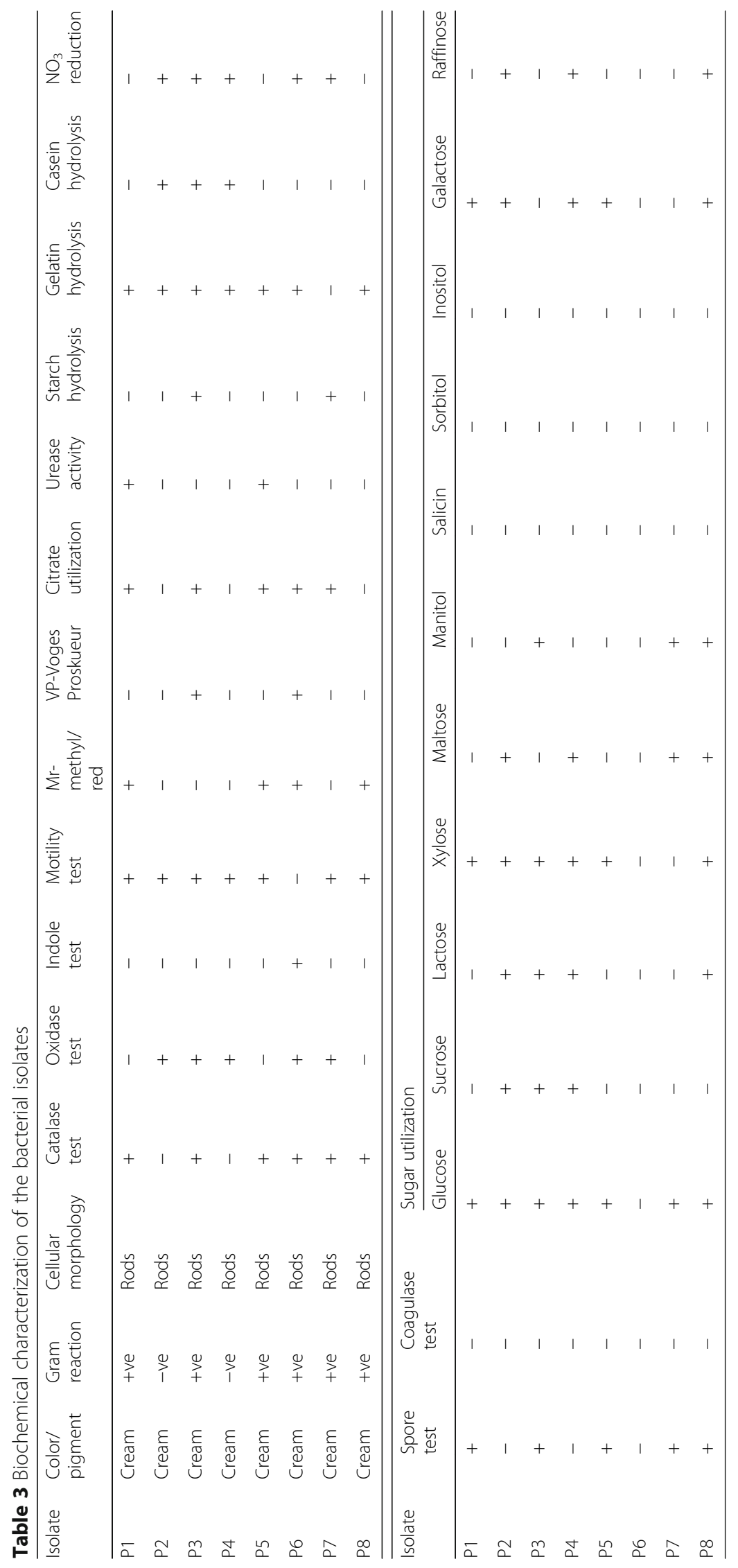


Table 4 Isolates' identities and accession number from NCBI

\begin{tabular}{lll}
\hline Isolates & Identity & Accession number \\
\hline P1 & Bacillus thuringiensis & MK875170 \\
P2 & Pseudomonas aeruginosa & MK875171 \\
P3 & Bacillus amyloliquefaciens & MK875172 \\
P4 & Pseudomonas aeruginosa & MK875173 \\
P5 & Bacillus cereus & MK875174 \\
P6 & Lysinibacillus fusiformis & MK875175 \\
P7 & Bacillus encimensis & MK875176 \\
P8 & Paraclostridium benzoelyticum & MK875177 \\
\hline
\end{tabular}

the functional groups in the control sample but at a reduced percentage. The strong and broad of alcohol was reduced by Lysinibacillus fusiformis by $44 \%$, carboxylic acid group or aliphatic asymmetric group was reduced by $22 \%$ while the carbonyl group or $\mathrm{C}=$ C stretch has a reduction of $35 \%$. There was more efficient reduction in all the functional groups by Bacillus encimensis than Bacillus cereus but not as efficient as Paraclostridium benzoelyticum and Lysinibacillus fusiformis (Fig. 4aa-e).

\section{Discussion}

Plants laden with mycorrhizal fungi have earlier been reported to enhance the phytoremediation efficiency of oil contaminated soils with high concentrations of heavy oil (Kuo et al. 2014). Interactions between plants and their attendant microbes (bacteria and fungi) need to be better understood to improve the effectiveness and feats of phytoremediation, in addition to the close interactions between bacteria and fungi (Jambon et al. 2018). Bell et al. (2014) reported that fungal associations may affect the condition of plants and the success of co-inoculated microbial strains during phytoremediation.

Results from this study showed that the inoculation of AM fungi into the soil promotes growth of maize plants on both uncontaminated soil and contaminated soil with the

Table 5 Hydrocarbon utilization by the bacteria isolates

\begin{tabular}{ll}
\hline Bacteria & Growth in oil \\
\hline Bacillus thuringiensis & - \\
Pseudomonas aeruginosa & + \\
Bacillus amyloliquefaciens & + \\
Pseudomonas aeruginosa & - \\
Bacillus cereus & +++ \\
Lysinibacillus fusiformis & +++ \\
Bacillus encimensis & +++ \\
Paraclostridium benzoelyti & +++ \\
\hline
\end{tabular}

Key: (-) no growth, (+) slight growth, and (+++) profuse growth
Table 6 Percentage of residual oil as degraded by bacteria isolates

\begin{tabular}{llll}
\hline Bacterial isolates & $\begin{array}{l}\text { Oil } \\
\text { concentration } \\
(\mathrm{ml})\end{array}$ & $\begin{array}{l}\text { Non-degraded } \\
\text { oil (ml) }\end{array}$ & $\begin{array}{l}\text { Percentage } \\
\text { degraded } \\
\text { oil (\%) }\end{array}$ \\
\hline Bacillus cereus & 5.00 & 4.4 & 12 \\
$\begin{array}{l}\text { Lysinibacillus fusiformis } \\
\text { Bacillus encimensi }\end{array}$ & 5.00 & 3.0 & 40 \\
$\begin{array}{l}\text { Paraclostridium } \\
\text { benzoelyticum }\end{array}$ & 5.00 & 4.0 & 20 \\
Control & 5.00 & 3.5 & 30 \\
\hline & 5.00 & 5.0 & 0 \\
\hline
\end{tabular}

highest concentration of spent engine oil at $\leq 75 \mathrm{mg} / \mathrm{kg}$ (Tables 1 and 2). Frey-Klett et al. (2005) reported Pseudotsuga menziesii-Laccaria bicolor symbiosis in the mycorrhizosphere, able to curb the formation of the Douglas-fir. Founoune et al. (2002) reported a robust association between the mycorrhizosphere source of fluorescent pseudomonads and the positive effect they have on the ectomycorrhizal symbiosis of Acacia holosericea-Pisolithus species. The shoot height and the number of leaves in maize plant grown in contaminated soil $(\mathrm{M}-\mathrm{C}+100 \mathrm{mg} / \mathrm{kg})$ and inoculated, contaminated soil $(\mathrm{M}+\mathrm{C}+100 \mathrm{mg} / \mathrm{kg}) \mathrm{had}$ a retarded growth after 6 weeks. This is in conformity with the report of Banks et al. (2003) who claimed that too much of contamination with spent engine oil significantly reduced plant height at every stages of growth. This finding was also supported by Abdulla (2010) who affirmed that AM fungi had more effect on peanut plants irrespective of substrate soil conditions. Table 3 revealed that four of the isolated bacteria were Gram-positive and four were Gram-negative.

The effect of contamination with spent engine oil and inoculation with AM fungi on the mean count of maize rhizosphere bacteria community obtained at 6 weeks of plating presented a total bacteria count ranging between $7.5 \times 10^{6}$ and $4.2 \times 10^{7} \mathrm{CFU} / \mathrm{g}$ for the $\mathrm{M}-\mathrm{C}+$ treatment with different concentration of spent engine oil and $8.0 \times$ $10^{6}$ to $1.18 \times 10^{8} \mathrm{CFU} / \mathrm{g}$ for the $\mathrm{M}+\mathrm{C}+$ treatment with different concentration of spent engine oil ranged (Figs. 1 and 2). This result is in agreement with the report of Onifade et al. (2007) and Stephen et al. (2013) who recorded high bacteria counts in crude oil polluted soils. Total bacterial counts in soil inoculated only with AM fungi $(\mathrm{M}+\mathrm{C}-)$ ranged from $2.23 \times 10^{7}$ to $1.02 \times 10^{8} \mathrm{CFU} /$ $\mathrm{g}$ while counts in the control $(\mathrm{M}-\mathrm{C}-)$ ranged from $3.0 \times$ $10^{6}$ to $3.1 \times 10^{7} \mathrm{CFU} / \mathrm{g}$, respectively (Figs. 1 and 2). Spini et al. (2018) reported that both bacterial and fungal communities found after 1 week of enrichment, resembled those detected after 4 weeks, while the soil depth did not affect the evolution of microbial populations. The coinoculation of bacteria and fungi is more advantageous for restoring the fertility of soil and the organic matter 
content with or without organic fertilizer than the use of single inoculum (Rashid et al. 2016).

The isolated bacteria, with persistent occurrences were identified as Bacillus thuringiensis (MK875170), Bacillus cereus (MK875174), Pseudomonas aeruginosa (MK875171 and MK875173), Bacillus amyloliquefaciens (MK875172), Lysinibacilus fusiformis (MK875175), Bacillus encimensis (MK875176) and Paraclostirdum benzoelyticum (Table 4). This result (Fig. 3) disagrees with the high occurrence of Pseudomonas, Sphingobacterium, Bacillus, Stenothrophomonas, Achromobacter, and Serratia reported by Spini et al. (2018).

Four of the isolates were able to utilize spent engine oil to a different degree (Tables 5 and 6). Lysinibacilus fusiformis (P6) degraded spent engine oil by $40 \%$, Paraclostirdum benzoelyticum (P8) degraded spent engine oil by $30 \%$, Bacillus encimensis (P7) by $20 \%$ while Bacillus cereus (P5) by $12 \%$ after 28 days of incubation. This finding is in line with the report of Onifade et al. (2007) and Ukaegbu and Mbakwem (2014), who noted that different bacteria species have different biodegradation capabilities. Vidalii (2001), Chaerun et al. (2004) and Nwaogu et al. (2008), asserted that biodegradation of spent oil by bacteria is a natural process by organic carbon sources, causing breakdown of petroleum components to lower molecular compounds or transferred into other compounds, sources of energy, cell mass, biological product in respiration, and metabolism. However, high degradation potential recorded for Lysinibacilus fusiformis is in agreement with the reports of Ayed et al. (2015). This may be due to the fact that Lysinibacilus fusiformis has the ability to survive in contaminated soils (Table 6).

The result of IR analysis (Fig. 4aa-e) showed that the residual oil from the bottles acted upon by Bacillus cereus (P6), Pseudomonas aeruginosa (P2 and P4), Bacillus amyloliquefaciens (P3), Lysinibacilus fusiformis (P6), Bacillus enecimensis (P7), and Paraclostirdum benzoelyticum (P8) have reduced alcohol, carboxylic acid, and carbonyl group after 28 days of incubation. This indicated that the four bacteria isolates utilized the spent oil component. This observation is in consonance with the report of Nwaogu et al. (2008), that many microorganisms have different rate at which they utilize hydrocarbons in soil and water.

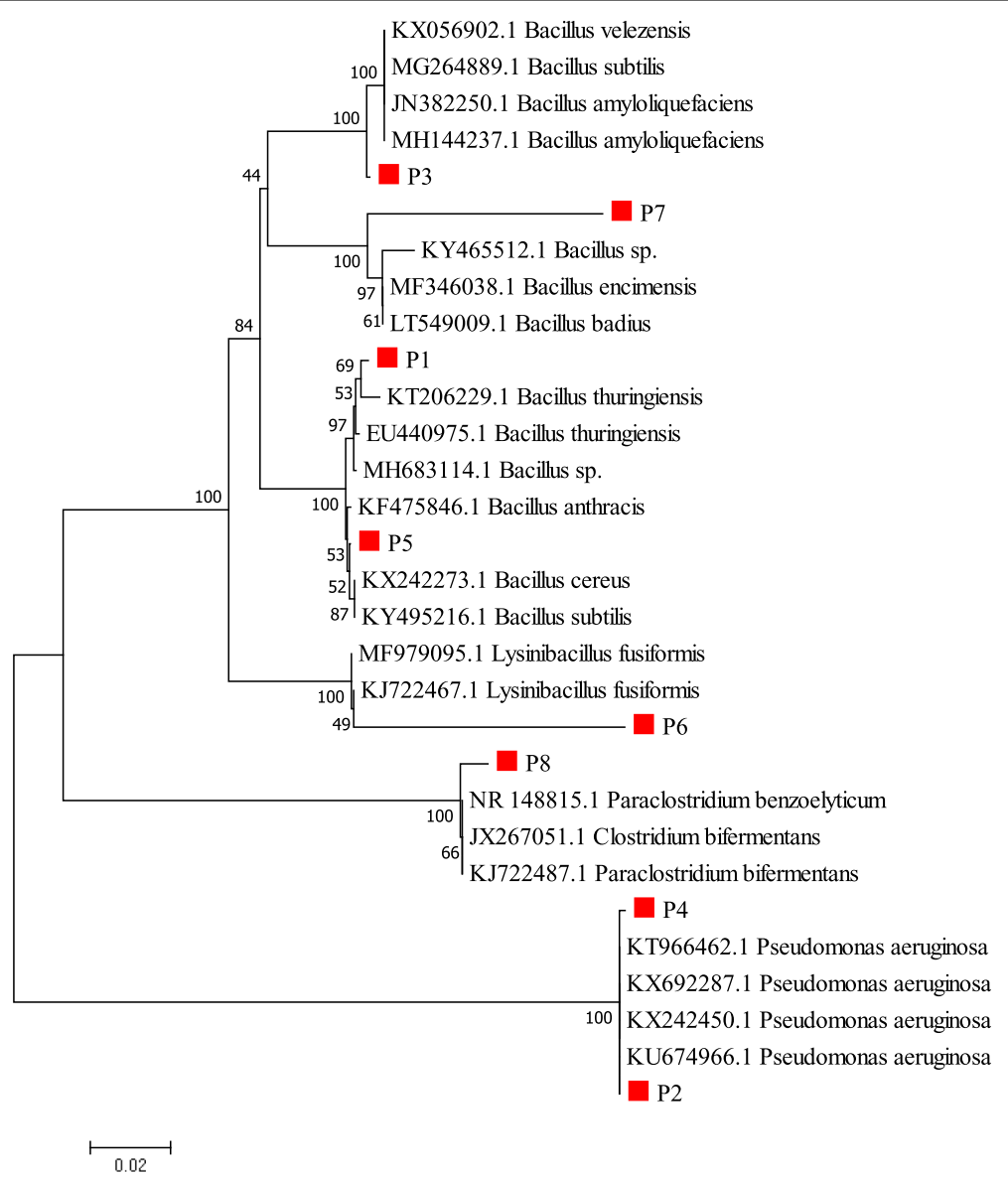

Fig. 3 Phylogenetic tree of isolates by neighbor joining method 
a

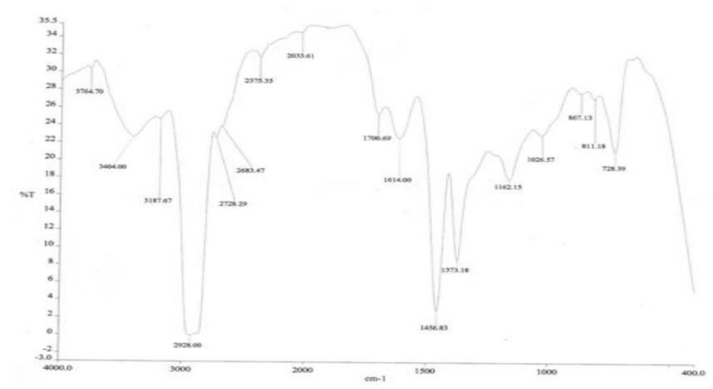

b

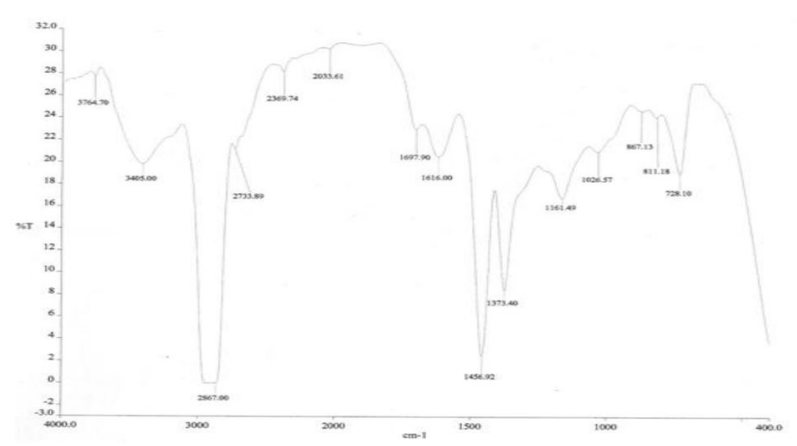

C

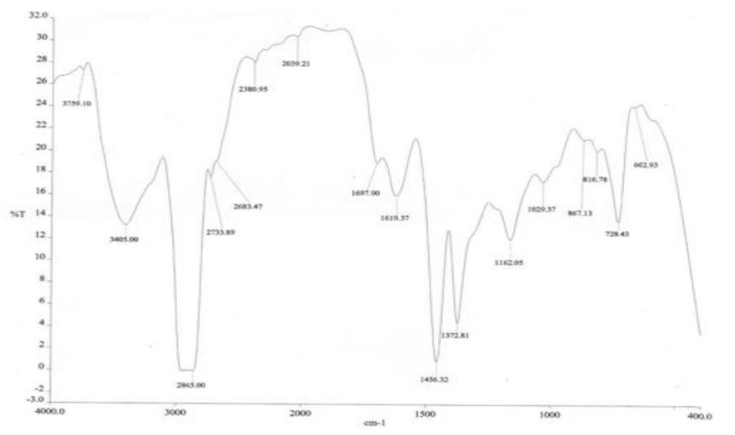

d

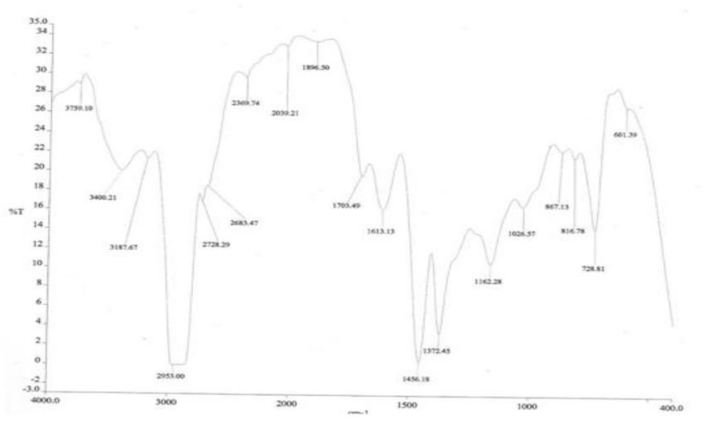

e

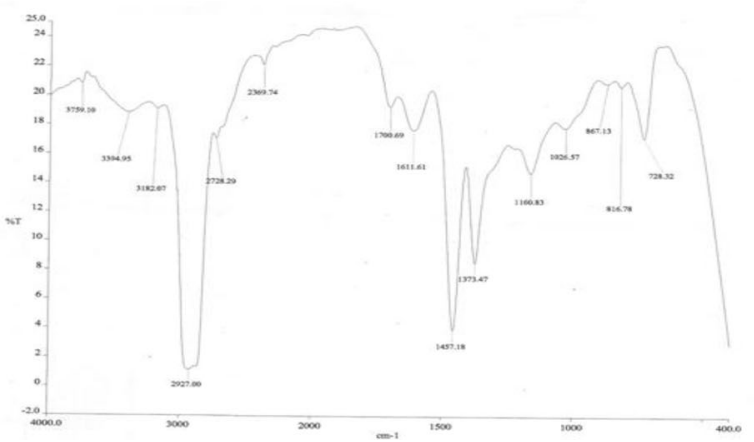

Fig. 4 a IR spectrum of untreated with engine oil (control). $\mathbf{b} I R$ spectrum of the used engine oil acted upon by Bacillus cereus. $\mathbf{c} I R$ spectrum of the used engine oil acted upon by Lysinibacillus fusiformis. $\mathbf{d}$ IR spectrum of the used engine oil acted upon by Bacillus encimensis. e IR spectrum of the used engine oil acted upon by Paraclostridium benzoelyticum

\section{Conclusion}

This study revealed that spent engine oil at a minimum value of $50 \mathrm{mg} / \mathrm{kg}$ with presence of arbuscular mycorrhiza fungus in the soil samples resulted in better growth for maize plant and higher total bacterial count. Arbuscular mycorrhiza fungus could be concluded to positively impact on the ability of rhizosphere bacteria in the degradation of spent engine oil during the growth of maize plant on contaminated soil.

\section{Acknowledgements}

The authors wish to appreciate the members of the PAB Department, LAUTECH; and the Staff members of Department of Science Laboratory, Federal Polythechnic, Ede and TETFUND.

\section{Authors' contributions}

ASB carried out the sample collection after obtaining the permission of the farm managers. He also carried out the lab work. MOL oversee the research work and also provided some of the materials required for the research. JAA also helped in the lab work, did the statistical analysis, and prepared the manuscript. AAA oversee the lab work, provided some of the materials used in the lab, and corrected the manuscript. The authors read and approved the final manuscript.

\section{Funding}

No funding was obtained from any external body during this study.

Availability of data and materials

Data obtained in this study will be available on request.

Ethics approval and consent to participate

No ethical approval was required for this study. 


\section{Consent for publication}

All authors agreed to publish this work in your reputed journal.

\section{Competing interests}

The authors declare that they have no competing interests.

\section{Author details}

'Department of Pure and Applied Biology, Faculty of Science, Ladoke Akintola University of Technology, P.M.B, Ogbomoso 4000, Nigeria. ${ }^{2}$ Department of Science Laboratory Technology, Federal Polytechnic, Ede Osun State, Nigeria. ${ }^{3}$ Department of Microbiology, University of Ilorin, Ilorin, Nigeria.

Received: 19 December 2019 Accepted: 27 February 2020

Published online: 25 March 2020

\section{References}

Abdulla Selah A-k (2010) Effect of arbuscular mycorrhization in sterile and non sterile soils. copyright $\odot$ penerbit Univ. Sains Malaysia. Trop Life Sci. Res 21:3-70

Aboribo RI (2001) Oil politics and the Niger Delta Development commission the tussle for control and domination. Afr. J. Environ. Stud. 2:168-175

Ajoy KM, Priyangshu MS, Bina Singh, Jeyascelan CP, Veeranna AC, Banwari Lai and Jayati Datta (2012). Bioremediation: An environment friendly sustainable biotechnology. Solution for remediation of petroleum hydrocarbon contaminated waste. ARPN J. Sci. and Technol., 2.special issue. ICESR. 1:3; 5-23.

Alexander M (1997) Introduction to Soil Microbiology. John Wiley and sons, New York

Alvarez P, Anid PJ, Vogel M (1991) Kinetics of aerobic biodegradation of benzene and toluene in sandy aquifer material. Biodegradation 2:43-51

Amao JA, Omojasola PF, Madhumita B (2019) Isolation and characterization of some exopolysaccharide producing bacteria from cassava peel heaps. Scientific African 4:e00093

Ayandele AA, Fagade OE, Adenegan AA (2012) Effect of ammonium salts on the biodegradation of used transformer oil using locally isolated microorganisms. Agric. and Biol. J. North America. 3:131-139

Ayed HB, Jemil N, Maalej H, Bayoudh A, Hmidet N and Nasri M (2015) Enhancement of solubilization and biodegradation of diesel oil by biosurfactant from Bacillus amyloliquefaciens An6. Int. Biodeterior. Biodegrad. 99:8-14

Banks MK, Kulakaw P, Schwab AP, Chen Z, Rathbone K (2003) Degradation of crude oil in the rhizosphere of sorghum bicolor. Inter. J. Phytoremediation 5 : $225-234$

Bell TH, El-Din HS, Lauron-Moreau A, Al-Otaibi F, Hiji M, Yergeau E, St-Arnaud M (2014) Linkage between bacterial and fungal rhizosphere communities in hydrocarboncontaminated soils is related to plant phylogeny. ISME J. 8:331-343

Chaerun SK, Tazaki K, Asada R, Kogure K (2004) Bioremediation of coastal areas 5 years after the Nakhodka oil spill in the Sea of Japan; Isolation and characterization of hydrocarbon degrading bacteria. Environ. Inter. 30:911-922

Founoune H, Duponnois R, Meyer JM, Ba AM, Chotte JL, Neyra M (2002) Interactions between ectomycorrhizal symbiosis and fluorescent Pseudomonads on Acacia holosericea: isolation of mycorrhization helper bacteria (MHB) from a soudano-sahelian soil. FEMS Microbiology and Ecology. 41:37-46

Frey-Klett P, Chavatte M, Clausse ML, Courrier S, Le Roux C, Raaijmakers J, Martinotti MG, Pierrat JC, Garbaye J (2005) Ectomycorrhizal symbiosis affects functional diversity of rhizosphere fluorescent pseudomonads. New Phytol. 165:317-328

Hashem A, Tabassum B and Abd_Allah EF (2019) Bacillus subtilis: A plant-growth promoting rhizobacterium that also impacts biotic stress. Saudi J. Biol. Sci. 26(6):1291-1297

Heider J. and Rabus R. (2008). Genomic Insights in the anaerobic biodegradation of organic pollutants microbia biodegradation; genomic and molecular biology. Caister Academic Press. UK

Jambon I, Thijs S, Weyens N, Vangronsveld J (2018) Harnessing plant-bacteriafungi interactions to improve plant growth and degradation of organic pollutants. J. Plant Interactions 13:1742-9153

Kuo HC, Juang DF, Yang L, Kuo WC, Wu YM (2014) Phytoremediation of soil contaminated by heavy oil with plants colonized by mycorrhizal fungi. Inter. J. Environ. Sci. Technol. 11:1661-1668
Nwite JN, Alu MO (2015) Effect of different levels of spent engine oil on soil properties grain yield of maize and its heavy metals uptakes in Abakaliki, southeastern Nigeria. J. Soil Sci. and Environ. Management. 6:92-99

Nwogu L.A., Igwe C.U. and Emejulu A.A (2008). Effects of Landolphia owariensis leaf extract on the liver function profile and haemoglobin concentration of albino rats. Afr. J. Biochem. Res. 2: 240-242

Onifade AK, Abubakar FA, Ekundayo FO (2007) Bioremediation of crude oil polluted soil in the Niger Delta area of Nigeria using enhanced natural alternation. J. Appl. Sci. 2:498-504

Rashid MI, Mujawar LH, Shahzad T, Almeelbi T, Ismail IMI, Oves M (2016) Bacteria and fungi can contribute to nutrients bioavailability and aggregate formation in degraded soils. Microbiol. Res. 183:26-41

Sada, P.O and O.I Odemerho (2000). Environmental issues and manag. Nig. Dev, 24-29

Sepahi AA, Golpasha ID, Emami M, Nakhoda AM (2008) Isolation andcharacterization of crude oil degrading Bacillus Spp. Iranian. Journal of Environmental Health Science \& Engineering 5(3):149-154

Spini G, Spina F, Poli A, Blieux AL, Regnier T, Gramellini C, Varese GC, Puglisi E (2018) Molecular and microbiological insights on the enrichment procedures for the isolation of petroleum degrading bacteria and fungi. Frontiers in Microbiology. 9:2543

Stephen E, Usman AS, Okolo MO, Akogu EA, Abioye OP (2013) Microbiological and physiochemical properties of diesel simulated soil. FUTA J. Res. Sci. 9:82-86

Teste F., Simard S., Durall D. M., Guy R. D., Jones M. D. and Schoonmaker A. L. (2009) Access to mycorrhizal networks and roots of trees: Importance for seedling survival and resource transfer. Ecology 90(10):2808-22

Ukaegbu-Obi K, Mbakwem-Aniebo (2014) Bioremediation potentials of bacteria isolated from rhizosphere of some plants of oil contaminated soil of Niger Delta. J. Appl. \& Environ. Microbiology 2:194-197

Vazquez M, Mar Cesar S, Azon R, Barea JM (2000) Interaction between arbuscular mycorrhizal fungi and other microbial moculants (Azospirillum, Pseudomonas, Trichoderma) and their effects on microbial population and enzyme activities in the rhizosphere of maize plants. Appl. Soil Ecol. 15:261-272

Vegter J.J., Lowe J., and Kasamas H. (2002). Sustainable management of contaminated land. An overview Austrian 28|page Federal Environmental Agency. p. 128

Vidali M. (2001). Bioremediation. An Overview. Pure Appl. Chem., 73: 1163-1172

\section{Publisher's Note}

Springer Nature remains neutral with regard to jurisdictional claims in published maps and institutional affiliations.

\section{Submit your manuscript to a SpringerOpen ${ }^{\circ}$ journal and benefit from:}

- Convenient online submission

- Rigorous peer review

- Open access: articles freely available online

High visibility within the field

- Retaining the copyright to your article

Submit your next manuscript at $\boldsymbol{\nabla}$ springeropen.com 